Ethiopian Journal of Environmental Studies \& Management 10(3): 340 - 350, 2017.

ISSN:1998-0507

doi: https://dx.doi.org/10.4314/ejesm.v10i3.5

Submitted: December 30, 2016

Accepted: April 17, 2017

\title{
QUANTITATIVE ESTIMATION OF POLLUTION IN GROUNDWATER AND SURFACE WATER IN BENIN CITY AND ENVIRONS
}

*AKOMA, 0.C. AND UHUNMWANGHO, 0.S.

Department of Basic Sciences (Microbiology option), Benson Idahosa University, P.M.B.1100 Benin City, Nigeria

\begin{abstract}
Microbiological and physico-chemical analyses of groundwater and surface water samples collected from different parts of Benin City were carried out to investigate their pollution load. Microbiological analyses were carried out using pour plate method and most probable number (MPN) technique while physico-chemical properties were investigated using standard analytical methods. Microbial colony counts were most prominent in Nutrient Agar medium with values ranging from $7 \times 10^{3} \mathrm{cfu} / \mathrm{ml}$ to $59 \times 10^{3} \mathrm{cfu} / \mathrm{ml}$, while counts in MacConkey and PDA ranged from $5 \times 10^{3} \mathrm{cfu} / \mathrm{ml}$ to $40 \times 10^{3} \mathrm{cfu} / \mathrm{ml}$ and $2 \times 10^{3}$ $\mathrm{cfu} / \mathrm{ml}$ to $8 \times 10^{3} \mathrm{cfu} / \mathrm{ml}$ respectively. Bacterial and fungal isolates were Bacillus spp. Klebsiella spp. Enterobacter spp. Micrococcus spp. Flavobacterium spp, Serratia marcescens, Aspergillus spp and Candida spp. The MPN result ranged from 1.0 $\times 10 \mathrm{MPN} / 100 \mathrm{ml}$ to $30.0 \times 10 \mathrm{MPN} / 100 \mathrm{ml}$. There was no record of fecal coliform count. Physico-chemical parameters were compared with regulatory standards from Federal Ministry of Environment for drinking water and they all fell within permissible limits except (Dissolved oxygen 28-30.55 $\mathrm{mgl}^{-1}$ ), total suspended solids (16-44.5mg/l), and Biological oxygen demand (8.3-76.5). This presents socio-economic and public health concerns. Constant monitoring is recommended to provide information on water quality and health guide.
\end{abstract}

Key Words: Microbial load, Physico-chemical properties, Water sources, Benin City

\section{Introduction}

Water is a basic resource and most important for life on earth. This resource is the most threatened aspect of life sustenance on earth. In 2005, the F.M.E report estimated consumable water levels to be at $2.7 \%$ of earth's water, with ground water being a major contributor. Recent survey estimates consumable water levels at $1 \%$ and shows that the

*Corresponding Author: Akoma, O.C.

Email: oakoma@biu.edu.ng decrease in percentage of consumable water is largely due to direct and/or indirect phenomena resulting in pollution (Sangodoyin and Agbawhe, 2007).

However, sustainable utilization of the earth's water is therefore being defined as the present use of water resources without affecting its availability whatsoever for use by future generations, which may arise through 
depletion of the resource or through a reduction in its quality (Kehinde, 1996). Water is categorized into ground water and surface water.

Surface water refers to water collecting on streams, rivers, lakes, dam, wetland or ocean. It is naturally replenished by precipitation and naturally lost through discharge to evaporation and sub-surface seepage into the ground water (Sangodoyin and Agbawhe, 2007). Ground water refers to water located beneath the ground surface in soil pore spaces and in the fractures of lithologic formations. When rain falls, much of it is absorbed into the ground, it moves downwards through pores and spaces in the rock until it reaches a dense layer of rock. The water trapped below the ground in the pores and spaces above the dense rock barrier is called ground water (Sangodoyin and Agbawhe, 2007).

Other common terms for ground water are aquifier or ground water aquifier. Ground water can be accessed through anthropogenic structures and equipment such as wells and boreholes. Generally, as a result of long retention time and natural filtering capacity of aquifers, groundwater is often unpolluted (Pearson and Rosenberg, 1998).

Increase industrial activities have led to pollutional stress on surface water both from industrial, agricultural and domestic sources (Ajayi and Osibanojo, 1981). Major streams in industrial areas of some Nigerian cities are already seriously polluted by waste from industries. Water pollution affects plants and organisms living in or on water and in almost all cases the effects are damaging either to individual species and population but also to the natural biological communities (Rice, 1996). Water pollution occurs when pollutants are discharged directly or indirectly into water bodies without adequate treatment to remove harmful compounds, (Obeng, 1981; Ajayi and Adeleye, 1997).

The principal contaminants of water include toxic chemicals, nutrients, biodegradable organisms, bacterial and viral pathogens, (Oguize, 2003; FME, 2005). Water is usually referred to as polluted when it is impaired by anthropogenic contaminants and either does not support human use, like serving as drinking water, and undergoes a marked shift in its ability to support its constituent biotic environments such as fish, natural phenomena such as volcanoes, algae bloom, storms and earthquakes and also cause major changes in water quality and the ecological status of water (Obasohan and Oronsaye, 2009).

Water pollution can serve as a threat to human health when pollutants enter the body via skin exposure or through the direct consumption of contaminated drinking water. Priority pollutants, including Dichlorodiphenyl trichloroethane (DDT) and polychlorinated biphenyls (PCBs) persist in the tissues of aquatic organisms, (Tawari-Fufeyin, 1998; Egborge and Fagade, 1999).

These persistent organic pollutants are transferred up the food chain in process called biomagnification and they can reach levels of concerns in fish species that are eaten by humans. Bacterial and Viral pathogens can pose a public health risk for those who drink contaminated water or eat raw shellfish 
from polluted water bodies (Sahlstrom, 2003).

Organic water pollutants include detergents, disinfection by products found in chemically disinfected drinking water such as chloform, food processing waste, which can include oxygen demanding substances, fats and grease, insecticides and herbicides, a huge range of organo halides and other chemical compounds, petroleum hydrocarbons, including fuels and lubricants (motor oil) and fuel combustion by products, from stormwater runoff, volatile organic compounds such as industrial solvents which are dense non-aqueous phase liquids (DNAPLs), may fall to the bottom of reservoirs, since they do not mix well with water and are denser (Wangboje and Oronsaye, 2001).

Fecal pollution of water from a health point of view is the contamination of water with microbial pathogens that may inhibit the gastrointestinal tract of mammals, but with particular attention to human fecal sources as the most relevant source of human illness globally. Ingestion of water contaminated with feces is responsible for a variety of diseases important to humans via what is known as the fecal oral route of transmission. Food, air, soil and all types of surfaces can also be important in the transmission of fecal pathogens, and thereby implicated in disease outbreaks. Most fecal micro-organisms however are not pathogenic. Indeed, some are considered beneficial to the host as they can out compete with pathogens for space and nutrients, complement the biochemical potential of the host gastrointestinal tract, and help in the development of the host immune system.
Nontheless, animal feces can also carry a number of important frank and oppurtunistic pathogens, capable of inflicting debilitating illness and, in some cases, death (Akpata and Ekundayo, 1998).

The occurrence of heavy metals in aquatic ecosystems in excess of natural background loads has become a problem of increasing concern. Heavy metals in the environment may accumulate to acutely toxic levels without visible signs. This may occur naturally from normal geological phenomenon such as ore formation, weathering of rocks and leaching or due to increased population, urbanization, industrial activities, agricultural practices, exploration and exploitation of natural resources (Ajayi and Osibanjo, 1981). Waste water streams containing heavy metals produced by many manufacturing processes and also find their way into the environment. Metals persist in the environment and become bioconcentrated and bioamplified along the food chain.

Colony counts are enumerations of the general population of heterotrophic bacteria present in water supplies. The enumerations may represent bacteria whose natural habitat is the water environment or those that have originated from soil or vegetation, (Pearson and Rosenberg, 2002). Many heterotrophic bacteria are able to multiply within the distribution system network by utilising nutrients derived either from fixtures and fittings or from assimilable or particulate organic carbon in the water. Changes in colony numbers may, therefore, be indicative of the use of inappropriate materials or changes in the quality of the source water, (Chambers et al., 2004). 
Aims and Objectives

1. To study the physico-chemical composition of some surface and ground water in Benin City.

2. To investigate the presence of microorganisms present in surface and underground water sources at periodic intervals with public health significance.

3. Recommend measures for ameliorating the adverse effects of water borne diseases.

\section{Materials and Methods \\ Sampling Stations}

Four sampling stations from different parts of Benin city were chosen in order to ensure a wide distribution of test samples. Sampling was done thrice within three months (March to May 2010). The sampling stations are: Ikpoba dam, Ogba river as surface water and GRA (Borehole), Oliha quarters (Borehole) as ground water.

\section{Sample Collection}

All Sample containers were properly labelled to fully establish its identity and were collected in a new sterile 1 liter plastic containers for microbiological analysis. Samples for physiochemical parameters were collected seperately in presterilize bottles. The oxygen was fixed in situ by the addition of $1.2 \mathrm{ml}$ each of winkler's solution. All samples were transported to the laboratory within 24hours of collection.
Ground water samples were collected from the point of discharge and surface water from the surface of the river.

\section{Identification of Bacteria and Fungi Isolates}

The bacteria isolate were identified by gram staining, also biochemical characteristics of the pure isolates were used to identify the isolates as shown in appendix 2. While fungi isolates were identified according to appearance, mycelia and spores.

\section{Physico-Chemical Analyses}

Water temperature was taken in situ with mercury in glass thermometer. Dissolved oxygen was fixed on site by adopting the alkali-azide modification of Winkler's method. Total dissolved solids, conductivity and colour were measured with a HACH DR2000 spectrophotometer. Turbidity measurement were expressed as Nephelmetric turbidity units (NTU) using an NTU turbidity model 100A.Cations and anions analyses for calcium, magmesium, potassium, iron, nitrate, sulphate, phosphate and silica were carried out as outlined by APHA (1998).

\section{Heterotrophic Plate Counts of Bacteria} and Fungi Colonies

Heterotrophic plate count on Nutrient agar, MacConkey agar, Potato Dextrose agar for the months of study. Are shown in fig. 1. 


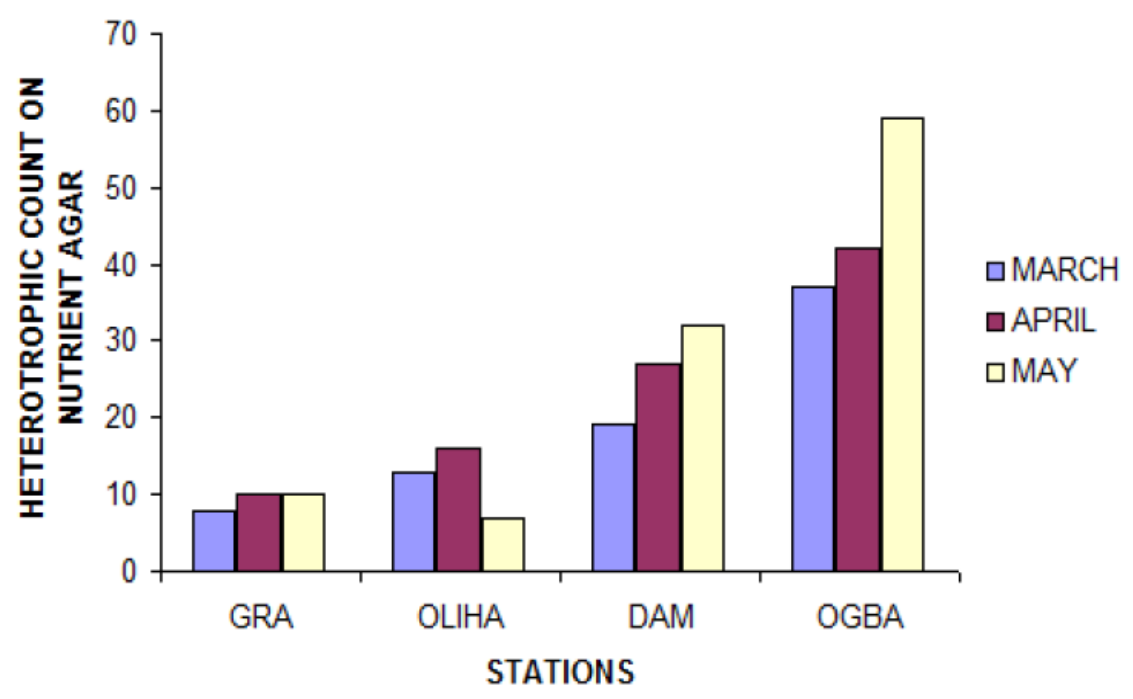

Fig. 1: Microbial Count on Nutrient Agar from the study stations

In the month of March, Ogba had the highest count with $37 \times 10^{3} \mathrm{cfu} / \mathrm{ml}$ followed by Dam with $19 \times 10^{3} \mathrm{cfu} / \mathrm{ml}$, Oliha with $13 \times 10^{3} \mathrm{cfu} / \mathrm{ml}$ and G.R.A had the lowest count with $8 \times 10^{3} \mathrm{cfu} / \mathrm{ml}$. Also, in the month of April Ogba had the highest count with $42 \times 10^{3} \mathrm{cfu} / \mathrm{ml}$, followed by Dam with $27 \times 10^{3} \mathrm{cfu} / \mathrm{ml}$,

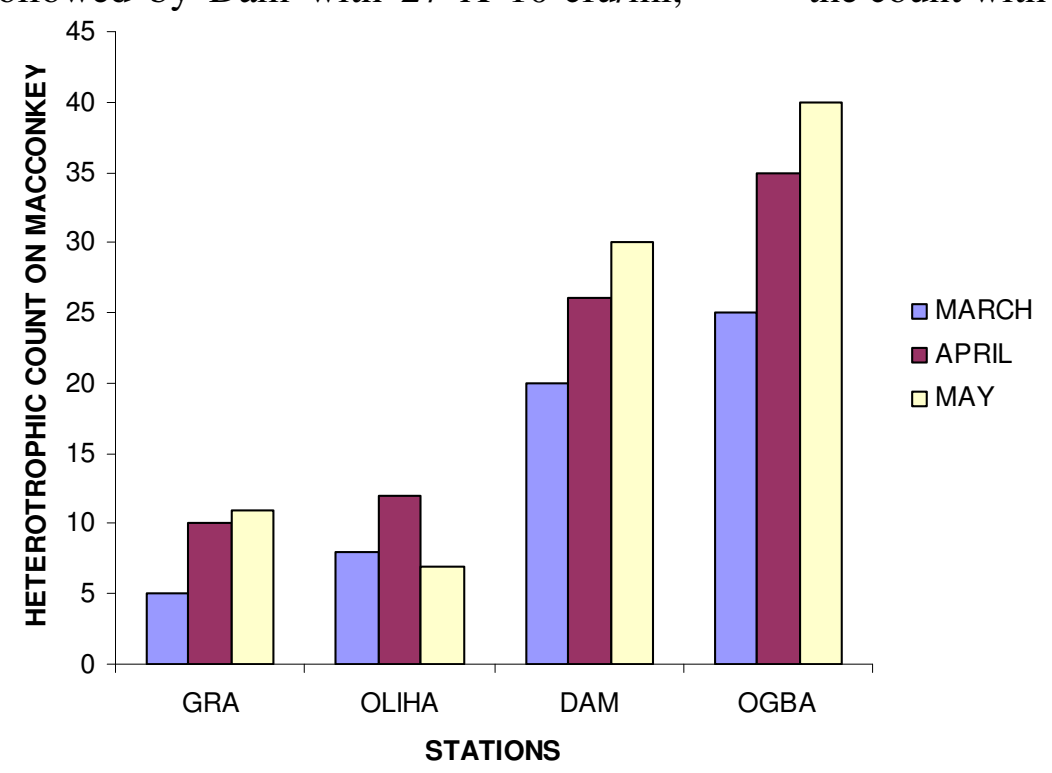

Oliha with $16 \times 10^{3} \mathrm{cfu} / \mathrm{ml}$ and GRA having the lowest count with $10 \mathrm{X}$ $10^{3} \mathrm{cfu} / \mathrm{ml}$. In the month of May Ogba also had the highest count with $59 \mathrm{X}$ $10^{3} \mathrm{cfu} / \mathrm{ml}$, followed by Dam with a count of $32 \times 10^{3,} \mathrm{cfu} / \mathrm{ml}$ GRA with a count of $10 \times 10^{3} \mathrm{cfu} / \mathrm{ml}$ and Oliha had lowest the count with $7 \times 10^{3} \mathrm{cfu} / \mathrm{ml}$.

Fig. 2: Microbial Count on Macconkey Agar For the study stations 
In the month of March, Ogba had the highest count with $25 \times 10^{3} \mathrm{cfu} / \mathrm{ml}$, followed by Dam with $20 \times 10^{3} \mathrm{cfu} / \mathrm{ml}$ Oliha with $8 \times 10^{3} \mathrm{cfu} / \mathrm{ml}$ and G.R.A had the lowest count with $5 \times 10^{3} \mathrm{cfu} / \mathrm{ml}$. Also, in the month of April Ogba had the highest count with $35 \times 10^{3} \mathrm{cfu} / \mathrm{ml}$ followed by Dam with $26 \times 10^{3} \mathrm{cfu} / \mathrm{ml}$,
Oliha with $12 \times 10^{3} \mathrm{cfu} / \mathrm{ml}$ and GRA having the lowest count with $10 \mathrm{X}$ $10^{3} \mathrm{cfu} / \mathrm{ml}$, In the month of May Ogba also had the highest count with $40 \mathrm{X}$ $10^{3} \mathrm{cfu} / \mathrm{ml}$, followed by Dam with a count of $30 \times 10^{3} \mathrm{cfu} / \mathrm{ml}$, GRA with a count of $11 \times 10^{3} \mathrm{cfu} / \mathrm{ml}$ and Oliha had lowest the count with $7 \times 10^{3} \mathrm{cfu} / \mathrm{ml}$.

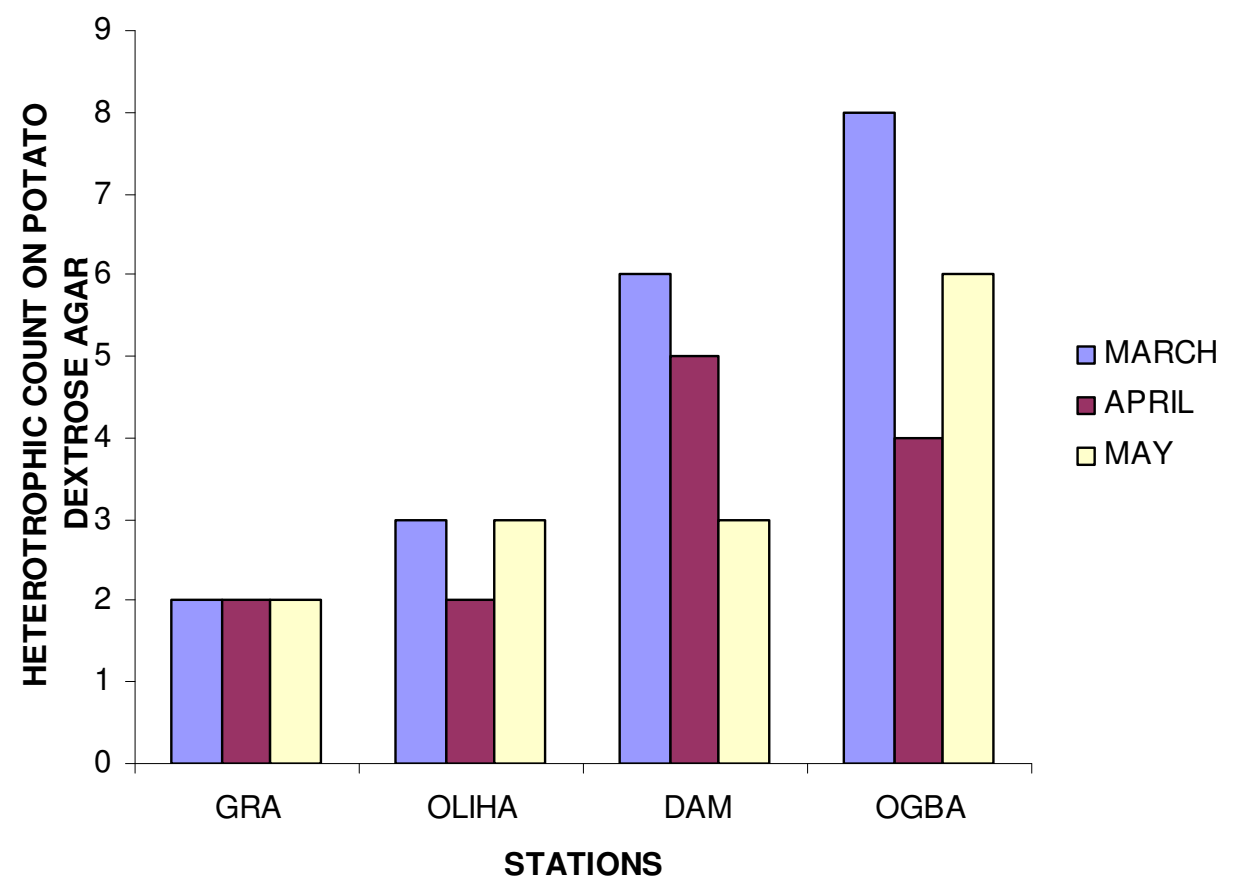

Fig. 3: Microbial Count on Potato Dextrose Agar for the study stations

In the month of March, Ogba had the highest count with $8 \times 10^{3} \mathrm{cfu} / \mathrm{ml}$, followed by Dam with $6 \times 10^{3} \mathrm{cfu} / \mathrm{ml}$, Oliha with $2 \times 10^{3} \mathrm{cfu} / \mathrm{ml}$ and G.R.A had the lowest count with $2 \times 10^{3} \mathrm{cfu} / \mathrm{ml}$ Also, in the month of April Dam had the highest count with $5 \times 10^{3} \mathrm{cfu} / \mathrm{ml}$, followed by Ogba with $4 \times 10^{3} \mathrm{cfu} / \mathrm{ml}$,
Oliha with $2 \times 10^{3} \mathrm{cfu} / \mathrm{ml}$ and GRA having count with $2 \times 10^{3} \mathrm{cfu} / \mathrm{ml}$. In the month of May Ogba a had the highest count with $6 \mathrm{X} 10^{3} \mathrm{cfu} / \mathrm{ml}$, followed by Dam with a count of $3 \times 10^{3} \mathrm{cfu} / \mathrm{ml}$, Oliha with a count of $2 \times 10^{3} \mathrm{cfu} / \mathrm{ml}$ and GRA had lowest the count with $2 \mathrm{X}$ $10^{3} \mathrm{cfu} / \mathrm{ml}$. 
Table 1: MPN Results for the Month of Study

\begin{tabular}{lllllll}
\multicolumn{2}{r}{ MARCH } & \multicolumn{2}{c}{ APRIL } & \multicolumn{2}{c}{ MAY } \\
\hline STATIONS & $\begin{array}{l}\text { TCC } \\
(\mathrm{mpn} / 100 \mathrm{ml})\end{array}$ & $\begin{array}{l}\text { FCC } \\
(\mathrm{mpn} / 100 \mathrm{ml})\end{array}$ & $\begin{array}{l}\text { TCC } \\
(\mathrm{mpn} / 100 \mathrm{ml})\end{array}$ & $\begin{array}{l}\text { TCC } \\
(\mathrm{mpn} / 100 \mathrm{ml})\end{array}$ & $\begin{array}{l}\text { FCC } \\
(\mathrm{Mpn} / 100 \mathrm{ml})\end{array}$ & $\begin{array}{l}\text { TCC } \\
\text { Mpn/100ml }\end{array}$ \\
\hline GRA & 3 & NIL & NIL & NIL & 1 & NIL \\
OLIHA & 20 & NIL & 8 & NIL & 14 & NIL \\
DAM & 20 & NIL & 11 & NIL & 17 & NIL \\
OGBA & 35 & NIL & 40 & NIL & 30 & NIL \\
\hline
\end{tabular}

TCC: Total coliform count, FCC: Fecal coliform count.

The MPN values for the total coliform count obtained for Oliha from the period of sampling ranged from 20 to $14 \mathrm{mpn} / 100 \mathrm{ml}$ and no growth recorded for the total fecal coliform count. Also
Ogba had MPN values ranging from 35 to $30 \mathrm{MPN} / 100 \mathrm{ml}$, while the MPN values obtained for GRA ranged from 3 to 1 MPN/100ml., and Dam had MPN values ranging from 10 to $17 \mathrm{MPN} / 100 \mathrm{ml}$. 
Table 2: Physico-chemical analysis of water samples for the month of study

\begin{tabular}{|c|c|c|c|c|c|c|c|c|c|c|c|c|}
\hline & DAM & & & OGBA & & & G.R.A & & & OLIHA & & \\
\hline PARAMETERS & March & May & Mean & March & May & Mean & March & May & Mean & March & May & Mean \\
\hline COLOR (Pt.Co.U) & 1 & 1 & 1 & 1 & 1 & 1 & ND & ND & & ND & ND & \\
\hline TURB (NTU) & 3 & 2 & 2.5 & 3 & 3 & 3 & 0 & 0 & 0 & 0 & 0 & 0 \\
\hline $\operatorname{TDS}\left(\mathrm{mgl}^{-1}\right)$ & 43 & 41 & 42 & 40 & 42 & 41 & 7 & 5 & 6 & 6 & 5 & 5.5 \\
\hline EC & 0.5 & 0.56 & 0.53 & 0.72 & 0.77 & 0.745 & 0.025 & 0.04 & 0.0325 & 0.03 & 0.04 & 0.035 \\
\hline $\mathrm{DO}\left(\mathrm{mgl}^{-1}\right)$ & 29 & 27 & 28 & 28.1 & 33 & 30.55 & 27.5 & 28.3 & 27.9 & 27.6 & 29.7 & 28.65 \\
\hline $\mathrm{pH}$ & 7.4 & 7.9 & 7.65 & 7.8 & 7.8 & 7.8 & 6.8 & 7.1 & 6.95 & 6.9 & 7.4 & 7.15 \\
\hline $\mathrm{BOD}_{5}$ & 74 & 79 & 76.5 & 52 & 49 & 50.5 & 9.3 & 8.7 & 9 & 8.6 & 8 & 8.3 \\
\hline $\mathrm{Fe}$ & 0.19 & 0.45 & 0.32 & 0.34 & 0.53 & 0.435 & 0.3 & 0.43 & 0.365 & 0.23 & 0.31 & 0.27 \\
\hline $\mathrm{NO}_{3}$ & 0.47 & 7 & 3.735 & 0.48 & 6.2 & 3.34 & 0.59 & 6.9 & 3.745 & 1.46 & 8.3 & 4.88 \\
\hline $\mathrm{SO}_{4}$ & 55 & 9.2 & 32.1 & 32 & 1.4 & 16.7 & 25 & 1.9 & 13.45 & 19 & 1.8 & 10.4 \\
\hline $\mathrm{PO}_{4}$ & 0.63 & ND & & 0.18 & ND & & 0.05 & ND & 0.05 & 0.18 & ND & 0.18 \\
\hline $\mathrm{Na}$ & 2.63 & 1.9 & 2.265 & 1.8 & 2.3 & 2.05 & 4.01 & 3.2 & 3.605 & 16.24 & 14.5 & 15.37 \\
\hline K & 6.43 & 1.6 & & 0.49 & 2 & & 2 & 1.7 & 1.85 & 4.22 & 10.9 & 7.56 \\
\hline $\mathrm{Ca}$ & 0.79 & 3.2 & 1.995 & 0.39 & 2.7 & 1.545 & 0.72 & 3.5 & 2.11 & 3.65 & 2.9 & 3.275 \\
\hline $\mathrm{Mg}$ & 0.08 & 0.48 & 0.28 & 0.01 & 0.41 & 0.21 & 0.12 & 0.38 & 0.25 & 1.33 & 0.86 & 1.095 \\
\hline $\mathrm{Cl}$ & 88.7 & 88.6 & 88.65 & 177.3 & 106.4 & 141.85 & 88.7 & 53.2 & 70.95 & 49.7 & 70.9 & 60.3 \\
\hline
\end{tabular}

ND: Not determined 
Quantitative Estimation of Pollution in Ground and Surface Waters...............KOMA \& UHUNMWANGHO

\section{Discussion}

Water quality is defined in terms of the pysical, chemical and biological content of water, (Obasohan and Oronsaye, 2009). The Physico-chemical and microbial characteristics of the water samples has been greatly influenced by natural and anthropogenic influences. Water is typically referred to as polluted when it is impaired by anthropogenic contaminants and either does not support human use, like serving as drinking water, bathing water, and undergoes a marked shift in its ability to support its constituent biotic communities such as fish, natural phenomena such as volcanoes, algae bloom, storms and earthquakes and also cause major changes in water quality and the ecological status of water (Obasohan and Oronsaye,2009).

The Bacterial isolated in this study include Bacillus spp, Klebsiella spp, Enterobacter spp, Microccocus spp, Flavobacterium spp, Serratia marcescens, while Aspergillus spp, and Candida spp were the fungi isolated from the water samples. Some of the bacterial isolated are part of the normal flora of some water, however, some of them such as Enterobacter, Klebsiella are part of the indicator coliform and their presence in water is an indirect reflection of human contamination of water sources.

The presence of certain microorganisms is often undesirable in any drinking water. When microorganisms are present in water, cycles of growth and decay of the cellular materials of the microorganisms may result in the production of by-products which may adversely affect the quality of the water supply (Levi, 2004).
The marked variation between the surface water samples and the underground water samples for the total coliform count results is suggestive of the degree of the of exposure of the respective water sources to man made influences and most of the value obtained for total coliform count are above the permmissible limit of drinking water. (FME 2005). And also most of the result obtained for fecal coliform count fall within the permissible standard for drinking water. The heterotrophic plate count values obtained are also above the permissible standard for drinking water.

Mean values obtained in physicochemical result, apart from dissolved oxygen, total suspended solids, Bilogical Oxygen Demand are within the permissible standards for drinking water (FME, 2005). The relatively high mean value recorded for dissolved oxygen, Total suspended solid and Biological oxygen demand is an indirect indication of the extent of biological activities which influence the concentration of oxygen in water, in addition to the weather and changes in the physical factors. Photosynthetic process increased the concentration of oxygen in water, while microbial activites place demand on oxygen levels for their metabolism (Ekhaise and Anyansi, 2005).

The result of this study are in constrast with result reported by Erah et al., (2002) who investigated the quality of ground in Benin city and identified E.coli and Fecal Streptococci and stated that some boreholes are sited indiscriminately in Districts in Benin City without proper geological surveys. Indiscriminate refuse and waste disposal and location of septic tanks, soak-away pits and pit-latrines in living 
surroundings are common. These activities could account for the presence of faecal bacteria in the borehole waters.

Although the result of this study indicates the presence of chemical and microbial contaminants which have health hazard implications, it cannot be assumed that the level of contamination will be the same in all areas in Benin City as seen in the difference between between Ogba and Dam, Oliha and GRA. However, there is an urgent need for public enlighteenment in Benin city and its environs on a need to treat borehole and surface water before drinking and observe good hygiene (Erah et al., 2002).

The government must seriously give the desired adequate attention to the supply of portable water to the inhabitants of Benin City. Routine monitoring of the groundwater and human activities within the City by the relevant government agency should ensure a reduction in the level of pollution of the waters coming from boreholes and surface water.

\section{Conclusion}

Water is life and access to good quality water cannot be overemphasized. Increased human activities in Benin City, particularly the indiscriminate location of septic tanks, soak-away pits and pitlatrines, disposal of refuse and waste, and other materials that can leach into the groundwater constitute a major health concern. Majority of the inhabitants of the City continue to consume water from boreholes and surface water without adequate and proper treatment. Some of the boreholes and surface watter in this study were contaminated with abnormal levels of metals and microorganisms with serious health hazards. This calls for public health education and routine monitoring of human activities in the City.

Further investigation is necessary to determine the health implication of the unacceptable levels of heavy metals and microbial contaminants of the groundwater and surface water observed in this study.

\section{References}

Ajayi, S.O. and Adeleye, S.A. (1997). Pollution studies on Nigeria Rivers , Preliminary report on the pollution level of the River Ona and Ogunpa. Bull. Chem. Soc. Nig. 2: 71-82.

Ajayi, S.O, Osibanjo, O. (1981). Pollution studies on Nigeria Rivers. II: Water quality of some Nigerian Rivers. Environ. Pollut. 2: 87-95.

Akpata, V.I. and Ekundayo, J.A. (1998). Faecal pollution of Lagos Lagoon. Nig. J. of Sci., 12: 39-53.

APHA (1998). American Public Health Association. Standard Methods for the Examination of Water and Wastewater, $20^{\text {th }}$ edition. American Water Works Association, Water Environment Federation, Washington D.C. 1287 pp.

Chambers, K., Creasey, J. and Forbes, L. (2004). Design and operation of distribution networks in Safe Piped Water. Managing Microbial Quality in Piped Distribution 44:35-38.

Egborge, A.B.M. and Fagade, S.O. (1999). Notes on the hydrobiology of the Wikki warm spring, Yankari Game Reserve, Nigeria. Pol. Arch.Hydrobiology 26(3): 313-322.

Ekhaise, F.O. and Anyasi, C.C. (2005). Influence of breweries effluent discharge on microbiological and 
physiochemical quality of Ikpoba river, Nigeria. African Journal of Biotechnology, 4(10): 1062-1065.

Ekhator, O., Akoma, O.C. and OgieOdia, E. (2011). A Comparative Limnological and Water Quality Assessment of some Rivers in Benin City and Peri-Urban Areas, Edo State, Nigeria. Global Research Journal of Microbiology, 2(1): 90 - 095.

Erah, O.P., Akujieze, N.C. and Oteize, G.E. (2002). The quality of Ground water in Benin-city: A baseline study on inorganic chemicals and microbial contaminants of health importance in boreholes and open wells. Tropical Journal of Pharmaceutical Research 1 (12): 75-82.

Federal Ministry of Environment. (2005).National guideline on water quality standards. Federal ministry of environment. $187 \mathrm{pp}$.

Kehinde, M.O. (1996). Impact of industrial growth on groundwater quality and availability. Environ. Pollution 66: 30-35.

Levi, Y. (2004). Composition of treated waters to minimise potential for microbial quality changes in Safe Piped Water. Managing Microbial Quality in Piped Distribution Systems, 30(8):19- 22.

Obasohan, E.E. and Oronsaye, J.A.O. (2009). Impact of urban wastewaters on the diversity and abundance of the fish population of Ogba River in Benin City, Nigeria. African journal of Biotechnology 8(10):2242-2250.
Obeng, L. (1981). Man's impact on tropical rivers. Journal of Water Microbiology, 11(4): 23-25.

Oguzie, F.A. (2003). Heavy metals in fish water and effluents of the lower Ikpoba river in Benin City, Nigeria. Pak. J. Sci. Ind. Res 46(3): 156-160.

Pearson, T.H. and Rosenberg, R. (1998). Macrobenthic succession in relation to organic enrichment and pollution of the marine environment. Ocean . Mar. Biol. Ann. 16: 229-311.

Rice, S.E. (1996). Water pollution as a case study. Water microbiology 15(3):15 -17.

Sahlstrom, L. (2003). A review of survival of pathogenic bacteria in organic waste used in biogas plants. Bioresour. Technol 87: 161-166.

Sangodoyin, A.Y. and Agbawhe, O.M. (2007). Environmental study on surface and groundwater pollutants from abattoir effluents. Bioresource Techno . 41: 193-200.

Tawari-Fufeyin, P.(1998). Heavy metal levels in some dominant fish of Ikpoba reservoir in Benin City. J.Env Rev., 2: 61-69.

Threlfall, E.J. (2002). Antimicrobial drug resistance in Salmonella problems and perspectives in food- and water-borne infections. FEMS Microbiol. Rev., 26(2): 141-148.

Wangboje, O. and Oronsaye, J.A.O.(2001). Bioaccumulation of Iron, Lead, Mercury,Copper, Zinc and Chromium by fish species from Ogba River, Benin City, Nigeria. Afr. J. Appl. Zool. Environ. Biol 3: 45- 49. 